\title{
Effects of atmospheric environmental changes on annual ring growth of Cryptomeria japonica in Southern Korea
}

\author{
Thi-Hoan Luong ${ }^{1}$, Kyoung-Soo Jang ${ }^{1}$, Woo-Jung Choi ${ }^{2}$, and Kye-Han Lee ${ }^{1, *}$ \\ ${ }^{1}$ Department of Forestry, Chonnam National University, Gwangju 500-757, Korea \\ ${ }^{2}$ Department of Rural and Biosystems Engineering, Chonnam National University, Gwangju 500-757, Korea
}

\begin{abstract}
Annual ring formation is considered a source of information to investigate the effects of environmental changes caused by temperature, air pollution, and acid rain on tree growth. A comparative investigation of annual ring growth of Cryptomeria japonica in relation to environmental changes was conducted at two sites in southern Korea (Haenam and Jangseong).Three wood disks from each site were collected from stems at breast height and annual ring growth was analyzed. Annual ring area at two sites increased over time $(p>0.05)$. Tree ring growth rate in Jangseong was higher than that in Haenam. Annual ring area increment in Jangseong was more strongly correlated with environmental variables than that in Haenam; annual ring growth increased with increasing temperature $(p<0.01)$ and a positive effect of $\mathrm{NO}_{2}$ concentration on annual ring area $(p<0.05)$ could be attributed to nitrogen deposition in Jangseong. The correlation of annual ring growth increased with decreasing $\mathrm{SO}_{2}$ and $\mathrm{CO}_{2}$ concentrations $(p<0.01)$ in Jangseong. Variation in annual growth rings in Jangseong could be associated with temperature changes and $\mathrm{N}$ deposition. In Haenam, annual ring growth was correlated with $\mathrm{SO}_{2}$ concentration $(p<0.01)$, and there was a negative relationship between precipitation $\mathrm{pH}$ and annual ring area $(p<0.01)$ which may reflect changes in nutrient cycles due to the acid rain. Therefore, the combined effects of increased $\mathrm{CO}_{2}, \mathrm{~N}$ deposition, and temperature on tree ring growth in Jangseong may be linked to soil acidification in this forest ecosystem. The interactions between air pollution $\left(\mathrm{SO}_{2}\right)$ and precipitation $\mathrm{pH}$ in Haenam may affect tree growth and may change nutrient cycles in this site. These results suggested that annual tree ring growth in Jangseong was more correlated with environmental variables than that in Haenam. However, the further growth of $C$. japonica forest at two sites is at risk from the long-term effects of acid deposition from fossil fuel combustion.
\end{abstract}

Keywords: annual tree ring, climate change, $\mathrm{CO}_{2}$ concentration, Japanese cedar, $\mathrm{N}$ deposition.

\section{INTRODUCTION}

Tree growth is affected by various environmental changes such as increased atmospheric $\mathrm{CO}_{2}$ concentration, temperature, atmospheric pollution, and nitrogen deposition (Chmura et al. 2011, Ito et al. 2011). The effects of these environmental factors on tree growth have been studied worldwide. Forest decline in Asia has been linked to acid precipitation (Hirano et al. 2007), air pollution and global warming (Woo 2009).

Impacts of atmospheric $\mathrm{NO}_{2}$ concentration on forest decline of Pinus densiflora in Japan have been reported by Kume et al. (2000) and decreases in annual ring width of Pinus thunbergii stands exposed to $\mathrm{SO}_{2}$ concentration have also been reported by Kim and Fukazawa (1997). A threat to C. japonica and Chamaecyparis obtusa forests in

\section{Open Access http://dx.doi.org/10.5141/ecoenv.2013.004}

This is an Open Access article distributed under the terms of the Creative Commons Attribution Non-Commercial License (http://creativecommons. org/licenses/by-nc/3.0/) which permits unrestricted non-commercial use distribution, and reproduction in any medium, provided the original work is properly cited.
Received 14 January 2013, Accepted 04 February 2013

*Corresponding Author

E-mail: khL@jnu.ac.kr

Tel: +82625302087 
Japan from soil acidification caused by increased nitrogen deposition have also been noted (Ito et al. 2011). As the effects of atmospheric pollutants and global warming are a consequence of long-term chronic exposure, gradual changes in forest growth, structure, and composition are observed (Kume et al. 2000, Chmura et al. 2011).

In Korea, tree ring formation and growth are considered useful sources of information for understanding the effects of environmental changes. Historical changes in tree growth can be evaluated from annual ring area as better tree growth produces a larger ring area. A few studies have already investigated relationships between annual ring growth and environmental changes in temperature, precipitation $\mathrm{pH}$, and atmospheric pollution for Pinus densiflora stands (Park and Yadav 1998, Choi et al. 2005, Kwak et al. 2009, Kwak et al. 2011). Information on growth responses of forest trees to historical environmental changes plays an important role in understanding how these changes have affected tree growth.

In this study, environmental factors that constrain or stimulate annual tree-ring growth of $C$. japonica (Japanese cedar) are concerned such as temperature, precipitation, atmospheric pollutants, and precipitation $\mathrm{pH}$ in southern Korea. Cryptomeria japonica is a fast growing species. It is widely planted in the warm-temperate forest zone, and plays an important role in the forests of Korea. This species appears to have promising potential for chronology-building and climatic reconstruction as it shows a sufficiently strong correlation between tree growth and climatic factors (Kojo 1987). Investigation into how environmental changes have historically affected annual ring area in different regions is one option for evaluating tree growth.

The objective of this study was to compare annual tree ring growth at two study sites in South Korea. The effects of climate factors (temperature and precipitation) and air pollution (acid precipitation, $\mathrm{NO}_{2}, \mathrm{SO}_{2}, \mathrm{O}_{3}$ and $\mathrm{CO}_{2}$ concentrations) on annual ring growth were examined.

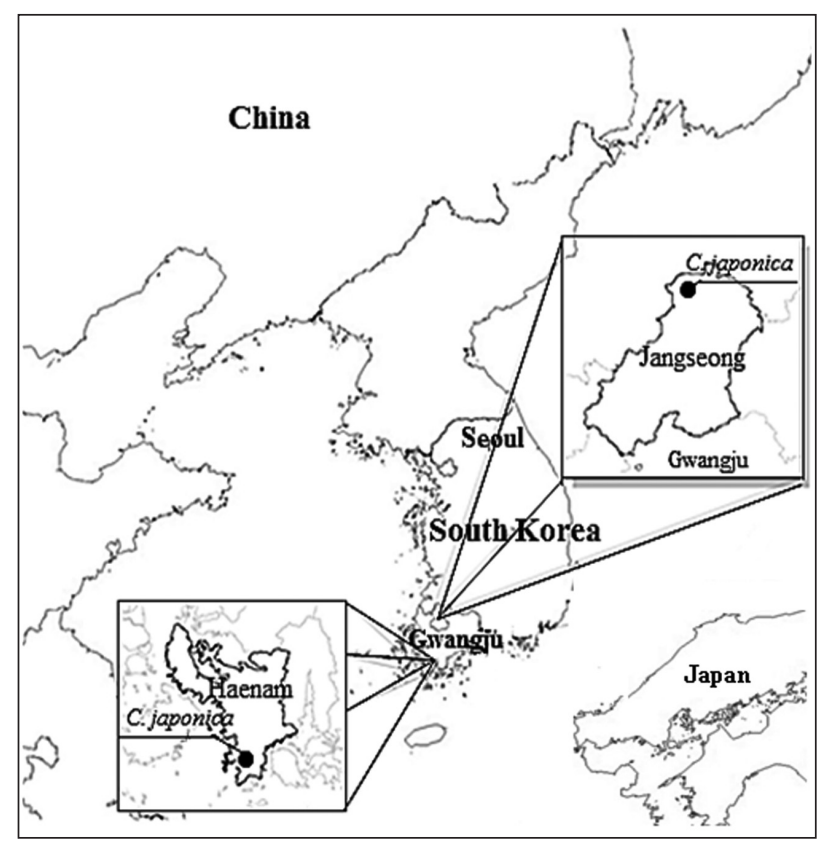

Fig. 1. Geographical locations of Cryptomeria japonica stands.

\section{MATERIALS AND METHODS}

\section{Description of the study sites}

The study was performed at two sites: Haenam $\left(34^{\circ} 21^{\prime} 28^{\prime \prime} \mathrm{N}, 126^{\circ} 33^{\prime} 38^{\prime \prime} \mathrm{E}\right)$ and Jangseong $\left(35^{\circ} 27^{\prime} 19^{\prime \prime} \mathrm{N}\right.$, $126^{\circ} 47^{\prime} 01^{\prime \prime} \mathrm{E}$ ) in southern Korea (Table 1, Fig. 1). The soil at these sites is classified as shallow gravelly silt loam with thin brown to dark brown color (Rural Development Administration of Korea 2000) with an average $\mathrm{pH}$ of 4.80 in Haenam (range: 4.66 to 4.98) and 4.35 in Jangseong (range: 4.30 to 4.44 ); total $\mathrm{C}$ concentration of $26.24 \mathrm{~g} \mathrm{C} \mathrm{kg}^{-1}$ in Haenam (range: 17.55 to 47.65 ) and $32.72 \mathrm{~g} \mathrm{C} \mathrm{kg}^{-1}$ in Jangseong (range: 8.40 to 78.84 ); total $\mathrm{N}$ of $2.32 \mathrm{~g} \mathrm{~N} \mathrm{~kg}^{-1}$ in Haenam (range: 1.34 to 3.82 ) and $3.09 \mathrm{~g} \mathrm{~N} \mathrm{~kg}^{-1}$ in Jangseong (range: 1.32 to 6.18 ) (Table 2).

The dominant understory vegetation at the study sites were Parthenocissus tricuspidata, Quercus serrata, Pteridium aquilinum, Rhus tricocarpa, Corylus heterophylla,

Table 1. Characteristics of location and tree ring growth in the study sites

\begin{tabular}{|c|c|c|c|c|c|c|}
\hline The site & $\begin{array}{l}\text { Latitude } \\
\text { (N) }\end{array}$ & $\begin{array}{l}\text { Longitude } \\
\text { (E) }\end{array}$ & $\begin{array}{c}\text { Altitude } \\
\text { (m a.s.l) }\end{array}$ & Slope & $\begin{array}{l}\text { Ring numbers } \\
\text { (years) }\end{array}$ & $\begin{array}{l}\text { Mean ring width } \\
(\mathrm{mm})^{*}\end{array}$ \\
\hline Haenam & $34^{\circ} 21^{\prime} 28^{\prime \prime}$ & $126^{\circ} 33^{\prime} 38^{\prime \prime}$ & 166 & $10^{\circ}$ & 35 & $3.57 \pm 0.23$ \\
\hline Jangseong & $35^{\circ} 27^{\prime} 19^{\prime \prime}$ & $126^{\circ} 47^{\prime} 01^{\prime \prime}$ & 218 & $15^{\circ}$ & 32 & $3.66 \pm 0.17$ \\
\hline
\end{tabular}

\#Values are the mean with standard error $(\mathrm{n}=3)$ 

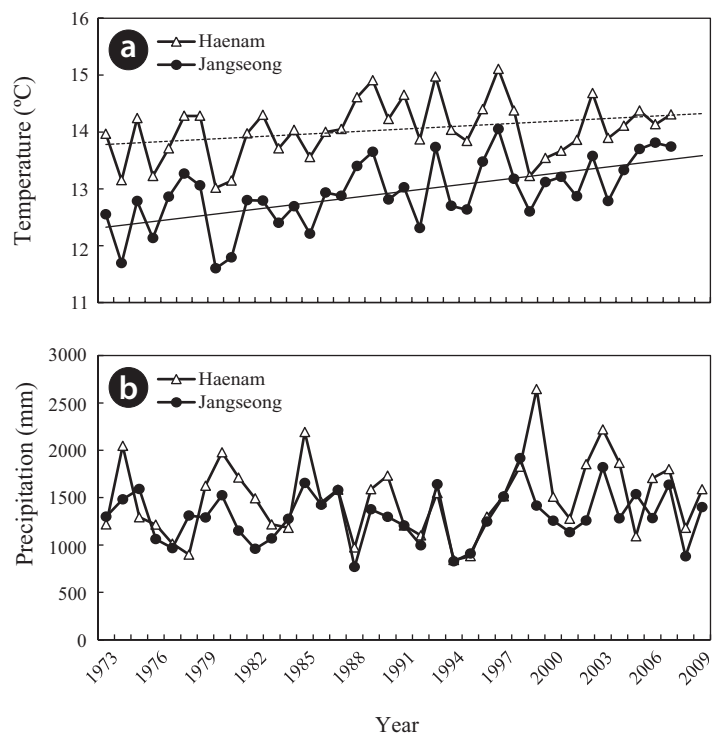

Fig. 2. Changes in mean annual temperature and precipitation in Haenam (a) and Jangseong (b).

Styrax japonicus, Zanthoxylum schinifolium, Stephanandra incisa, Lindera glauca, Paederia scandens, etc.

\section{Environmental data}

The environmental data set used for the correlation analysis included climate variables (temperature and precipitation), atmospheric pollutants $\left(\mathrm{NO}_{2}, \mathrm{SO}_{2}, \mathrm{O}_{3}\right.$, and $\mathrm{CO}_{2}$ ), and precipitation $\mathrm{pH}$. At each study site, all the meteorological and environmental monitoring data were obtained at two monitoring stations. For Haenam, climate variables were obtained from the Wando monitoring station located $14 \mathrm{~km}$ from the study site; atmospheric pollutant concentrations were obtained from the Mokpo monitoring station. In Jangseong, atmospheric pollutant concentrations were obtained from the Gwangju monitoring station, while climate variables were obtained from the Jeongup monitoring station, which is $14 \mathrm{~km}$ from the study site (Ministry of Environment of Korea 2010). During the 37 year period between 1973 and 2009 for which climate data are available, the mean annual temperature and precipitation were $14.0^{\circ} \mathrm{C}$ and $1496.7 \mathrm{~mm}, 13.0^{\circ} \mathrm{C}$ and

Table 2. Soil chemical properties in the study sites

\begin{tabular}{lccc}
\hline The site & $\begin{array}{c}\text { Carbon } \\
\left(\mathbf{g ~ k g}^{-1}\right)\end{array}$ & $\begin{array}{c}\text { Nitrogen } \\
\left(\mathbf{g ~ k g}^{-1}\right)\end{array}$ & $\mathbf{p H}^{\#}$ \\
\hline Haenam & 26.24 & 2.32 & $4.80 \pm 0.04$ \\
Jangseong & 32.72 & 3.09 & $4.35 \pm 0.02$ \\
\hline
\end{tabular}

"Values are the mean \pm SE based on triplicated measurements
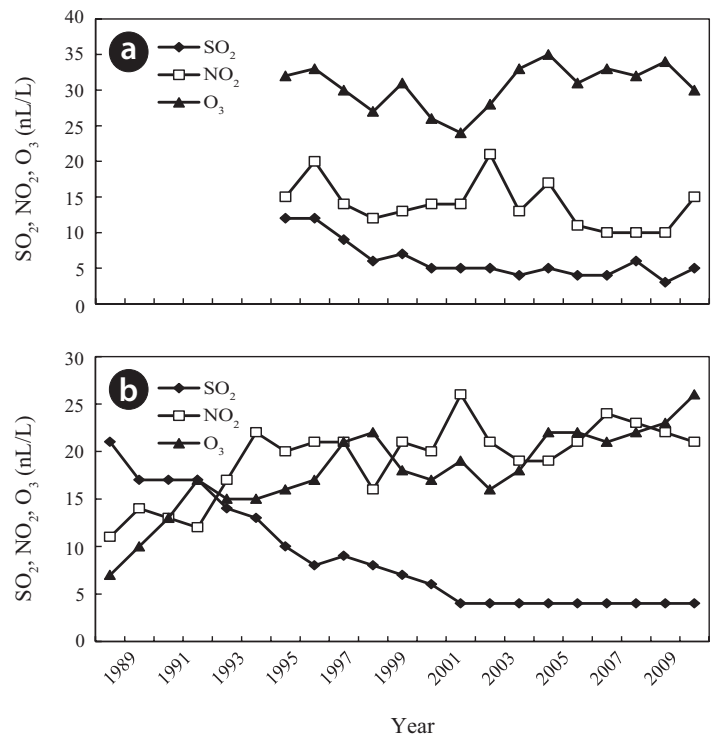

Fig. 3. Changes in mean concentration of atmospheric pollutants in Haenam (a) and Jangseong (b).

1304.1 mm in Haenam (Wando), Jangseong (Jeongup), respectively (Fig. 2).

At Haenam (Mokpo) station between 1995 and 2009, mean annual $\mathrm{SO}_{2}$ concentration decreased from 12.0 to $4.0 \mathrm{~nL} \mathrm{~L}^{-1}$, while mean annual concentrations of $\mathrm{NO}_{2}$ and $\mathrm{O}_{3}$ fluctuated between 10.0 and $20.0 \mathrm{~nL} \mathrm{~L}^{-1}$ and between 24.0 and $35.0 \mathrm{~nL} \mathrm{~L}^{-1}$, respectively (Fig. 3a). At Jangseong (Gwangju) station, atmospheric pollutant concentration data were available from 1989 to 2009. During this period, mean annual $\mathrm{SO}_{2}$ concentration decreased from 21.0 to $4.0 \mathrm{~nL} \mathrm{~L}^{-1}$, while mean annual concentrations of $\mathrm{O}_{3}$ and $\mathrm{NO}_{2}$ increased from 7.0 to $26.0 \mathrm{~nL} \mathrm{~L}^{-1}$ and from 11.0 to 21.0 $n L^{-1}$, respectively (Fig. 3b).

At Gwangju station, atmospheric $\mathrm{CO}_{2}$ concentration increased from $370.7 \mathrm{ppm}$ in 1999 to $392.5 \mathrm{ppm}$ in 2009 (Fig. 4a). The mean precipitation $\mathrm{pH}$ at two sites showed a decreasing trend from 5.8 to 4.5 in Haenam (Mokpo) and from 5.5 to 4.9 in Jangseong between 1992 and 2009 (Fig. $4 b)$.

\section{Annual tree ring analysis}

A $20 \times 20$ m plot was established at each study site and randomly selected trees were cut down to collect tree-ring disks (Table 1). Three tree-ring disks were collected at breast height at each site. The ages of tree disks at the study sites were determined and ranged from 35- to 37-years old in Haenam, and from 32- to 34-years old in Jangseong.

Tree ring samples were sanded and polished to measure 

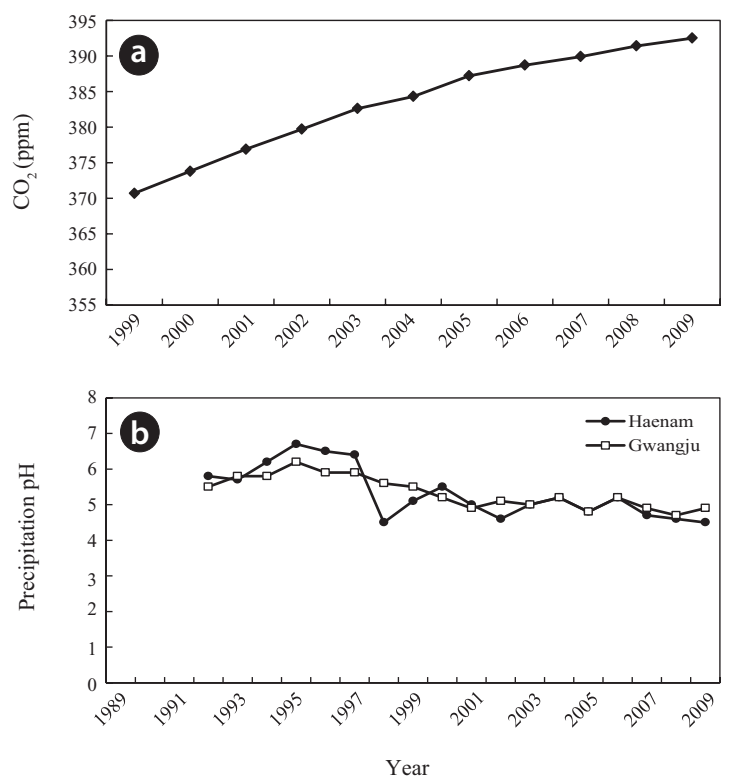

Fig. 4. In mean $\mathrm{CO}_{2}$ concentration (a) and precipitation $\mathrm{pH}(\mathrm{b}$ ) in study sites.

the ring width. The ring width measurement was based on four radii for each disk sample. The radii were crossdated to identify to exact year in which each tree ring was formed (Baillie and Pilcher 1973). The ring widths of the disk were measured along each radius with an accuracy of $0.01 \mathrm{~mm}$, using the program CDendro and CooRecorder 7.4 (Cybis Elektronik and Data AB, Salsjobden, Sweden). The annual basal area increments were calculated assuming that tree rings are concentric circles to minimize agerelated growth trends of ring width and were used as an indicator of tree growth (Choi et al. 2007). The annual ring growth was calculated as an average for each region.

\section{Statistical analysis}

Response and correlation function analysis (Blasing et al. 1984) was used to examine relationships between annual ring growth and climate variables (temperature and precipitation), atmospheric pollutants $\left(\mathrm{SO}_{2}, \mathrm{NO}_{2}, \mathrm{O}_{3}\right.$, and $\mathrm{CO}_{2}$ ), and precipitation $\mathrm{pH}$ (Kwak et al. 2011). Response function analysis is a form multiple regression. Because variation in annual ring width was likely to be affected by multiple environmental factors, these relationships were explored by Pearson correlation analysis.

All the response and correlation functions were determined for the period 1973-2009, which was common to both tree-ring data and the regional climate records. For relationships between air pollutants and annual ring area, the response and correlation functions were determined
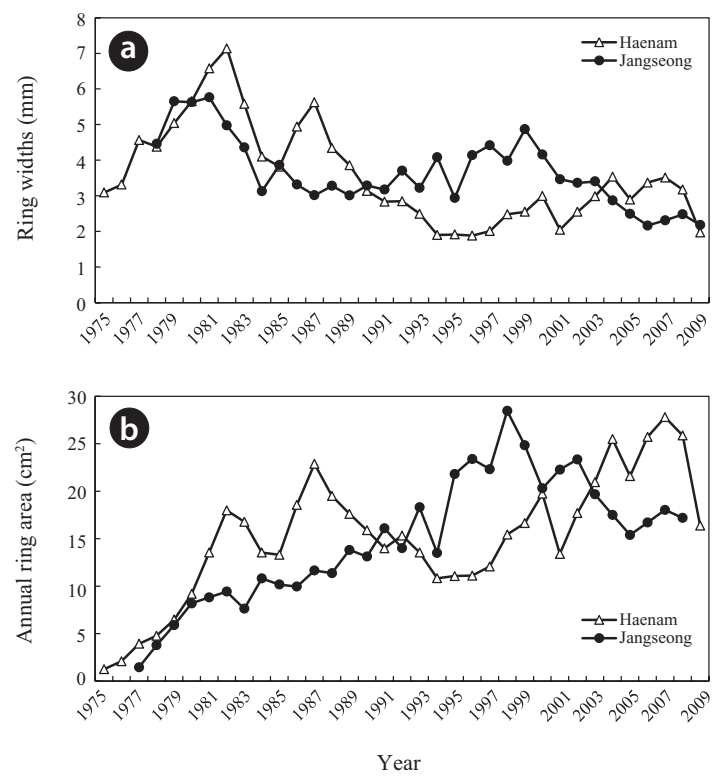

Fig. 5. Annual ring width growth (a), and annual ring area (b) of C. Japonica in the study sites.

for $\mathrm{SO}_{2}, \mathrm{NO}_{2}$, and $\mathrm{O}_{3}$ from 1995 in Haenam, and 1989 in Jangseong, for precipitation $\mathrm{pH}$ from 1992 in Haenam and Jangseong, for $\mathrm{CO}_{2}$ concentration from1999 at both sites. Therefore, the determination of these relationships was conducted using annual data.

All statistical analyses were performed using SPSS 11.5 statistical software package (SPSS, Chicago, Illinois, USA). The level of significance for all statistical tests was an $\alpha$ value of 0.05 . The significance of annual trends of tree ring growth was assessed by the analysis of time series using year as an independent variable.

\section{RESULTS}

\section{Variation in annual ring growth}

Annual ring growth rates among the two sites were not significantly different $(p>0.05)$, but the growth of annual rings within each site was significantly different $(p<0.01)$. Annual growth ring widths at all sites showed a decreasing pattern over time (Fig. 5a). Variation in annual ring widths in Jangseong had the high growth rate of $0.09 \mathrm{~mm}$ compared to that in Haenam. Mean tree ring widths were 3.57 $\mathrm{mm}$ in Haenam and $3.66 \mathrm{~mm}$ in Jangseong (Table 1).

Annual ring area in the all sites increased over time $(p$ $>0.05$ ). However, annual ring area in Jangseong increased up until 1998 and thereafter it decreased gradually, whereas in Haenam it increased gradually (Fig. 5b). 


\section{Relation of environmental factors with annual ring growth}

Annual ring growth in Jangseong was positively correlated $(p<0.05)$ with temperature; this correlation was not significant at Haenam (Table 3). Annual ring growth at both sites was not affected by precipitation. For regression analysis, the significant correlation of temperature with annual ring growth in Jangseong was not useful for estimating past temperature because the correlation coefficient was too small (data not shown).

The effects of atmospheric pollutants such as acid precipitation, $\mathrm{NO}_{2}, \mathrm{SO}_{2}, \mathrm{O}_{3}$ and $\mathrm{CO}_{2}$ on the tree-ring growth differed between sites. Annual ring growth in Haenam was negatively correlated with $\mathrm{SO}_{2}$ concentration ( $p<$ 0.01 ) but not related with $\mathrm{NO}_{2}, \mathrm{O}_{3}$, and $\mathrm{CO}_{2}$ concentrations. Annual ring growth in Jangseong was positively correlated with $\mathrm{NO}_{2}$ concentration $(p<0.05)$ and negatively correlated $(p<0.05)$ with $\mathrm{SO}_{2}$ and $\mathrm{CO}_{2}$ concentrations (Table 3). Precipitation $\mathrm{pH}$ was negatively correlated ( $p<$ 0.01 ) with annual ring growths in Haenam; there was no effect at Jangseong (Table 3).

Inter-correlations of annual ring area (y) with air pollution and acid precipitation were assessed using linear correlation for multiple regressions at the two sites. In Jangseong, y was positively correlated with $\mathrm{CO}_{2}$ and $\mathrm{NO}_{2}$ ( $\left.\mathrm{y}=-0.47 \mathrm{CO}_{2}-0.61 \mathrm{NO}_{2}+212.77, r^{2}=0.90, p<0.001\right)$. In Haenam, this equation was correlated with precipitation $\mathrm{pH}\left(\mathrm{y}=-4.91 \mathrm{pH}+44.0, r^{2}=0.40, p<0.01\right)$.

Table 3. Pearson correlation between annual ring area and environmental variables in the study area

\begin{tabular}{lcc}
\hline \multirow{2}{*}{ Variable $^{\mathrm{a}}$} & \multicolumn{2}{c}{ Pearson correlation coefficients } \\
\cline { 2 - 3 } & \multicolumn{2}{c}{ Ring area } \\
Haenam & Jangseong \\
\hline Temperature & $0.18^{\mathrm{ns}}(35)$ & $0.40^{*}(32)$ \\
Precipitation & $0.31^{\mathrm{ns}}(35)$ & $0.16^{\mathrm{ns}}(32)$ \\
$\begin{array}{c}\text { Atmospheric } \mathrm{SO}_{2} \\
\text { concentration }\end{array}$ & $-0.72^{\text {*** }}(15)$ & $-0.56^{* * *}(21)$ \\
Atmospheric $\mathrm{NO}_{2}$ & $-0.51^{\mathrm{ns}}(15)$ & $0.43^{*}(21)$ \\
$\quad$ concentration & & \\
Atmospheric $\mathrm{O}_{3}$ & $0.44^{\mathrm{ns}}(15)$ & $0.38^{\mathrm{ns}}(21)$ \\
$\begin{array}{c}\text { concentration } \\
\text { Atmospheric } \mathrm{CO}_{2} \\
\text { concentration }\end{array}$ & $0.58^{\mathrm{ns}}(11)$ & $-0.89^{* * * * *}(11)$ \\
Precipitation $\mathrm{pH}$ & $-0.63^{* * *}(18)$ & $-0.04^{\mathrm{ns}}(18)$ \\
\hline
\end{tabular}

${ }^{a}$ Values in the parentheses are the number of data used for the correlation analysis

${ }^{* * *} p<0.001 ;{ }^{* *} p<0.01 ;{ }^{*} p<0.05 ;{ }^{\text {ns }}$ Not significant

\section{DISCUSSION}

Annual ring growth varied markedly among the trees ( $\mathrm{n}$ $=3$ ) at each site, but the increment in annual ring growth was not different between sites $(n=2)$ (Fig. 5, Table 1$)$. This suggests that variation in annual ring increment of individual trees depends on the environmental factors at each site such as climate, air pollution, and soil fertility. A positive correlation of temperature with annual ring area increment of trees in Jangseong was suggested that annual ring growth increased with increasing temperature. Lebourgeois et al. (2005) suggested that the positive effect of increased temperature on tree-ring growth might be related with soil water capacity. In Jangseong, mean annual precipitation was $1,304 \mathrm{~mm}$ (Fig. 2b), but this was not correlated with annual ring area. Thus, this site might have adequate moisture for tree growth. However, the lack of correlation between temperature and precipitation at this site may be due to the periods of water limitation (Savard 2010). Temperature changes between 1973 and 2009 were about from $0.1^{\circ} \mathrm{C}$ to $1.5^{\circ} \mathrm{C}$ which were about $1^{\circ} \mathrm{C}$ lower comparing to temperature in Haenam (Fig. 2a). Increases in temperature might be directly affecting tree growth and indirectly through interactions with other stressors and disturbances (Chmura et al. 2011), but at Haenam, tree growth was not affected by temperature. The correlation between temperature and annual ring area in Jangseong has analyzed the regression model. Temperature has been claimed to be relatively unimportant for tree growth. Increase in tree growth in Jangseong may be extending the combination of increases in nitrogen deposition, $\mathrm{CO}_{2}$ concentration, and temperatures (Hyvönen et al. 2007, Bytnerowicz et al. 2007).

There were significant correlations between atmospheric pollutants and annual tree-ring growth at Haenam and Jangseong. The negative correlation between $\mathrm{SO}_{2}$ concentration and mean annual ring increment in Haenam and Jangseong (Table 3) suggested that annual ring growth increased with decreasing $\mathrm{SO}_{2}$ concentration. In a previous study, decreases in atmospheric $\mathrm{SO}_{2}$ concentration due to national policy were not considered high enough to affect tree growth (Kume et al. 2000). Therefore, the significant effect of $\mathrm{SO}_{2}$ concentration on increased growth of annual ring area in Haenam and Jangseong could be due to the acid deposition (Kwak et al. 2011). A significant relationship between $\mathrm{NO}_{2}$ concentration and annual ring area of trees in Jangseong (Table 3) could be attributed to annual ring area increment increasing with $\mathrm{NO}_{2}$. In an earlier study, the rate of forest decline of $P$. densiflora in Japan was negatively correlated with atmo- 
spheric $\mathrm{NO}_{2}$ concentration (Kume et al. 2000). The positive effect of $\mathrm{NO}_{2}$ concentration on annual tree ring area in Jangseong may be attributed to nitrogen deposition that can have various effects on forests (Kwak et al. 2011, Bytnerowicz et al. 2007). Increasing $\mathrm{CO}_{2}$ concentration between 1999 and 2009 (Fig. 4a) affected annual tree-ring growth of $C$. japonica at Jangseong. The influence of increased $\mathrm{CO}_{2}$ on annual ring growth could be direct effects on physiological processes of photosynthesis, respiration, and transpiration (McPherson et al. 1994, Chapin III et al. 2009, Chmura et al. 2011). Increases in $\mathrm{CO}_{2}$ concentration may reflect both growth and water use efficiency of plants (Bytnerowicz et al. 2007). In this study, annual ring growth decreased with increasing $\mathrm{CO}_{2}$ concentration because of stomatal closure or assimilated by leaves that activates photosynthetic enzyme (Kwak et al. 2009, Choi and Lee 2012). This result was consistent with the study of Clark et al. (2003) who found reductions in tree growth with increased atmosphere $\mathrm{CO}_{2}$ concentration in tropical rain forest. The significant correlation between $\mathrm{CO}_{2}$ concentration and annual ring area at Jangeong suggests that elevated atmospheric $\mathrm{CO}_{2}$ might be attributable to changes in tree growth rings (Yazaki et al. 2004).

For regression analysis at Jangseong, the combination of both $\mathrm{CO}_{2}$ and $\mathrm{NO}_{2}$ concentrations was positively correlated with annual ring area; this correlation suggested that annual ring growth increased with increased $\mathrm{CO}_{2}$ and elevated nitrogen deposition (Bytnerowicz et al. 2007). $\mathrm{N}$ deposition originated from $\mathrm{NO}_{2}$ (Kwak et al. 2011, Bytnerowicz et al. 2007) is claimed to be the most important factor of the increased tree growth. In effect, total $\mathrm{N}$ concentration in soil in Jangseong was $3.09 \mathrm{~g} \mathrm{~kg}^{-1}$ and it was higher than that in Haenam (Table 2); this may be the reason why annual ring widths in this site were larger than that in Haenam. Increased $\mathrm{CO}_{2}$ could lead to stomata closure to protect the plant from air pollution (Bytnerowicz et al. 2007). Therefore, integrated effects of elevated $\mathrm{CO}_{2}$, $\mathrm{N}$ deposition and climate changes on tree growth may be linked to acid deposition (Bytnerowicz et al. 2007) because of soil acidification with an average $\mathrm{pH}$ of 4.35 (Ito et al 2011) in Jangseong.

Acid deposition is formed from $\mathrm{NO}_{2}, \mathrm{SO}_{2}$, and $\mathrm{O}_{3}$ due to the burning of fossil fuels. At Haenam, the negative correlation between precipitation $\mathrm{pH}$ and annual ring area (Table 3) may reflect decreases in annual ring growth with increasing precipitation $\mathrm{pH}$ between 1992 and 2009. This correlation may also be linked to nitrogen deposition (Kwak et al. 2009b, Kwak et al. 2011) due to the $\mathrm{H}^{+}$ input from acid rain (Shan 1998).The nitrogen content from acid precipitation can be sufficient to stimulate tree growth (Shan 1998). The decreasing precipitation $\mathrm{pH}$ (Fig. 4b) may seem to reflected increased $\mathrm{N}$ deposition originated from $\mathrm{NO}_{\mathrm{x}}$ emission that is known to be depleted in ${ }^{15} \mathrm{~N}$ relative to the soil mineral $\mathrm{N}$ due to soil acidification (Kwak et al. 2011). The soil was acidic with pH of below 5.5 (Pritchett \& Fisher 1987). In our study, mean $\mathrm{pH}$ value of soil in Haenam was 4.8 and total $\mathrm{N}$ concentration in soil was $2.32 \mathrm{~g} \mathrm{~kg}^{-1}$ (Table 2), and leaching of nutrients at this site with the acid deposition may result in changes in growth (Ito et al. 2011). Long-term acid deposition may also have altered forest structure and function (McNulty and Boggs 2010). The effect of increased precipitation acidity on decreased tree ring growth may be attributed to changes in forest nutrient cycles such changed soil nitrogen dynamics (Choi et al. 2007). The significant correlation between precipitation $\mathrm{pH}$ and annual ring area in Haenam also suggests that tree ring data might be useful as an indicator of precipitation pH. Kwak et al. (2009b, 2011) also suggested that tree ring chemistry of $P$. densiflo$r a$ may be used to estimate historical precipitation acidity in Korea. Therefore, the combination between $\mathrm{SO}_{2}$ concentration and precipitation $\mathrm{pH}$ may form the acid deposition and affect tree growth of C. japonica in Haenam.

\section{CONCLUSIONS}

1. At two study sites in southern Korea, annual ring growth of C. japonica was correlated with environmental factors and annual increment of ring area was not different between regions. However, the growth rate of annual ring width in Jangseong was higher than that in Haenam because of the higher mineral $\mathrm{N}$ concentrations in the soil.

2. At all sites, the annual tree-ring growth was affected by integration of climate change and atmospheric pollutants in the forest ecosystem of Jangseong. The positive correlations of temperature and $\mathrm{NO}_{2}$ concentration with annual ring growth of trees could suggest that the ring growth increased with increasing temperature and nitrogen deposition in Jangseong. In addition, the negative effects of $\mathrm{SO}_{2}$ and $\mathrm{CO}_{2}$ concentrations on tree-ring growth might be reflected in the increase in annual ring area with decreased atmospheric $\mathrm{SO}_{2}$ and $\mathrm{CO}_{2}$ concentrations due to national policy and the respiration of plants by inhibiting photosynthesis in Jangseong. Therefore, the majority of increased annual ring growth of trees in this site could interact among increased temperature, nitrogen deposition, and $\mathrm{CO}_{2}$. However, effects of atmospheric $\mathrm{SO}_{2}, \mathrm{NO}_{2}$, $\mathrm{CO}_{2}$ on annual growth rings were affected by air pollu- 
tion in forest ecosystem. The combination of effects of atmospheric pollutants and temperature changes on tree growth might be the problem of acidification in the forest ecosystem of Jangseong.

3. In Haenam, a negative correlation of tree-ring growth with $\mathrm{SO}_{2}$ and precipitation $\mathrm{pH}$ might be reflected in the nitrogen deposition, and these correlations may be changes in forest nutrient cycles caused by the acid rain. Precipitation $\mathrm{pH}$ affected the annual growth of trees in Haenam and annual ring growth might be useful as an indicator to estimate precipitation $\mathrm{pH}$.

4. These results suggested that annual ring growth of C. japonica in Jangseong was more correlated with environmental variables than that in Haenam. However, the radial growth at two sites might be affected by changes in nitrogen deposition and climate. The further growth of $C$. japonica forest is at risk from the long-term effects of acid deposition from fossil fuel combustion. To sustain forest productivity in each site, changes in silviculture practice such as forest soil management practice may be employed in future studies.

\section{ACKNOWLEDGMENTS}

This study was supported by a grant (code: S121010 L010000) from Forest Science and Technology Projects, Korea Forest Service.

\section{LITERATURE CITED}

Baillie MGL, Pilcher JR. 1973. A simple cross dating program for tree ring research. Tree-Ring Bull 33: 7-14.

Blasing TJ, Solomon AM, Duvick DN. 1984. Response functions revisited. Tree-Ring Bull 44: 1-15.

Bytnerowicz A, Omasa K, Paoletti E. 2007. Integrated effects of air pollution and climate change on forests: A northern hemisphere perspective. Environ Poll 147: 438-445.

Chapin III FS, McFarland J, McGuire AD, Euskirchen ES, Ruess RW, Kielland K. 2009. The changing global carbon cycle: linking plant-soil carbon dynamics to global consequences. J Ecol 97: 840-850.

Chmura DJ, Anderson PD, Howe GT, Harrington CA, Halofsky JE, Peterso, DL, Shaw DC, St.Clair JB. 2011. Forest responses to climate change in the north western United State: Ecophysiological foundation for adaptive management. For Ecol and Manage 261: 1121-1142.

Choi WJ, Lee SM, Chang SX, Ro HM. 2005. Variations of $\delta^{13} \mathrm{C}$ and $\delta^{15} \mathrm{~N}$ in Pinus densiflora tree rings and their relation- ship to environmental changes in Eastern Korea. Wat Air Soil Poll 164: 173-187.

Choi WJ, Chang SX, Bhatti JS. 2007. Drainage affects tree growth and $\mathrm{C}$ and $\mathrm{N}$ dynamics in a Minerotropic Peatland. Ecology 2: 443-453.

Choi WJ, Lee KH. 2012. A short overview on linking annual tree ring carbon isotopes to historical changes in atmospheric environment. For Sci Tech 8: 73-78.

Clark DA, Piper SC, Keeling CD, Clark DB. 2003. Tropical rain forest tree growth and atmospheric carbon dynamics linked to interannual temperature variation during 1984-2000. Proc Nat Acad Sci 100: 5852-5857.

Hirano Y, Mizoguchi T, Brunner I. 2007. Root parameters of forest tree as sensitive indicators of acidifying pollutants: a review of research of Japanese forest trees. J For Res 12: 134-142.

Ito K, Uchiyama Y, Kurokami N, Sugano K, Nakanishi Y. 2011. Soil acidification and decline of trees in forests within the precincts of Shrines in Kyoto (Japan). Wat Air Soil Poll 214: 197-204.

Kim JK, Fukazawa K. 1997. Changes in tree ring width and density of Pinus thunbergii growing in the vicinity of industrial complex in Korea. J For Res 2: 109-113.

Kojo Y. 1987. A dendrochronological study of Crytomeria japonica in Japan. Tree Ring Bull 47: 1-21.

Kume A, Tsuboi N, Satomura T, Suzuki M, Chiwa M, Nakane K, Sakurai N, Horikoshi T, Sakugawa H. 2000. Physiological characteristics of Japanese red pine, Pinus densiflora Sieb. et Zucc., in declined forests at Mt. Gokurakuji in Hiroshima Prefecture, Japan. Trees 14: 305-311.

Kwak JH, Lim SS, Park HJ, Lee SI, Lee KH, Kim HY, Chang SX, Lee SM, Ro HM, Choi WJ. 2009. Relating tree ring chemistry of Pinus densiflora to precipitation acidity in an industrial area of South Korea. Wat Air Soil Poll 199: 9-106.

Kwak JH, Lim SS, Chang SX, Lee KH, Choi WJ. 2011. Potential use of $\delta^{13} \mathrm{C}, \delta^{15} \mathrm{~N}, \mathrm{~N}$ concentration, and $\mathrm{Ca} / \mathrm{Al}$ of Pinus densiflora tree rings in estimating historical precipitation pH. J Soil Sed 11: 709-721.

Lebourgeois F, Breda N, Ulrich E, Granier A. 2005. Climatetree-growth relationships of European beech (Fagus sylvatica L.) in the French Permanent Plot Network (RENECOFOR). Trees 19: 385-401.

McNulty SG, Boggs JL. 2010. A conceptual framework: Redefining forest soil's critical acid load under a changing climate. Environ Poll 158: 2053-2058.

McPhersonEG, Nowak DJ, Rowntree RA. 1994. Chicago's urban forest ecosystem: Results of the Chicago urban forest climate project. General Technical Report NE-186. Radnor, PA, United States pp: 63-64.

Ministry of Environment of Korea. 2010. Annual reports of 
ambient air quality in Korea. Ministry of Environment, Seoul (in Korean).

Park WK, Yadav RR. 1998. A dendroclimatic analysis of Pinus densiflora from Mt. Chiri in southern Korea. Ann For Sci. 55: 451-459.

Pritchett WL, Fisher RF. 1987. Properties and management of forest soils. $2^{\text {sd }}$ ed. John Wiley and Sons publishing pp: 190.

Rural Development Administration of Korea. 2000. Detailed Korea Soil Map. Rural Development Administration, Seoul, Korea.

Sarvard MM. 2010. Tree-ring stable isotopes and historical perspectives on pollution-An overview. Environ Poll.
158:2007-2013.

Shan Y. 1998. Effects of simulated acid rain on Pinus densiflora: inhibition of net photosynthesis by the pheophytization of chlorophyll. Wat Air Soil Poll 103: 121-127.

Yazaki K, Ishida S, Kawagishi T, Fukatsu E, Maruyama Y, Kitao M, Tobita H, Koike T, Funada R. 2004. Effects of elevated $\mathrm{CO}_{2}$ concentration on growth, annual ring structure and photosynthesis in Larix kempferi seedling. Tree physiol 24: 941-949.

Woo SY. 2009. Forest decline of the world: A linkage with air pollution and global warming. Afr J Biotechnol. 8: 7409-7414. 